\title{
openheart A nutraceutical strategy for downregulating TGF $\beta$ signalling: prospects for prevention of fibrotic disorders, including post-COVID-19 pulmonary fibrosis
}

\author{
James J DiNicolantonio (D , ${ }^{1}$ Mark F McCarty, ${ }^{2}$ Jorge Barroso-Aranda, ${ }^{3}$ \\ Simon Assanga, ${ }^{4}$ Lidianys Maria Lewis Lujan, ${ }^{4}$ James H O'Keefe (D) ${ }^{5}$
}

To cite: DiNicolantonio JJ, McCarty MF, Barroso-Aranda J, et al. A nutraceutical strategy for downregulating TGF $\beta$ signalling: prospects for prevention of fibrotic disorders, including post-COVID-19 pulmonary fibrosis. Open Heart 2021;8:e001663. doi:10.1136/ openhrt-2021-001663

Accepted 30 March 2021

Check for updates

(c) Author(s) (or their employer(s)) 2021. Re-use permitted under CC BY-NC. No commercial re-use. See rights and permissions. Published by BMJ.

${ }^{1}$ Preventive Cardiology, Saint Luke's Mid America Heart Institute, Kansas City, Missouri, USA

${ }^{2}$ Catalytic Longevity, Encinitas, California, USA

${ }^{3}$ Clinica Libre de Adicciones, Tijuana, Mexico

${ }^{4}$ Department of Research and Postgraduate Studies in Food, University of Sonora, Sonora, Mexico

${ }^{5}$ University of Missouri-Kansas City, Saint Lukes Mid America Heart Institute, Kansas City, Missouri, USA

Correspondence to Dr James J DiNicolantonio; jjdinicol@gmail.com

\section{OVERVIEW OF TRANSFORMING GROWTH FACTOR-} BETA SIGNALLING

Upregulated transforming growth factorbeta (TGF $\beta$ ) signalling, driving mesenchymal cells to increase their production of ground substance and undergo a transition to a myofibroblast phenotype, is believed to play a pathogenic role in diverse fibrotic disorders, including benign prostatic hyperplasia, scleroderma, pulmonary fibrosis, glomerulosclerosis, tubulointerstial fibrosis, hepatic fibrosis, open angle glaucoma, Peyronie's disease and the cardiac fibrosis associated with cardiac hypertrophy and heart failure. ${ }^{1-20}$ It should follow that safe, practical measures which downregulate such signalling may have potential for the prevention and control of these syndromes. Nutraceutical measures with this property have particular promise, as they might be employed for primary prevention. This issue is now of particular interest, as pulmonary fibrosis is emerging as a not-uncommon long-term complication of COVID-19. ${ }^{212}$

TGF $\beta$ signalling commences when this ligand binds to the type II TGF $\beta$ receptor (TßRII), inducing its association with the type I receptor (T $\beta R I)$ to form a heterotrimer complex. The constitutive serine-threonine kinase activity of TRRII then phosphorylates T $\beta R I$, activating its dual-specificity kinase activity. Smad2 or Smad3 then bind to T $\beta R I$, which phosphorylates it on a serine. This phosphorylation enables Smad2/3 to complex with Smad4, forming a heterodimer which translates to the nucleus to serve as a transcription factor to promote expression of TGF $\beta$-inducible genes.
However, the Smad2/3-Smad4 heterodimer quite frequently functions in concert with an AP-1 complex to mediate TGF $\beta$-induced transcription. ${ }^{23-28}$ Activation of AP-1 reflects concurrent TGF $\beta$-mediated activation of the mitogen-activated protein (MAP) kinases ERK, JNK and p38. ${ }^{29}{ }^{30}$ Activation of the MAP kinase kinase kinase TAK1 is upstream from JNK and p38 MAP kinase in this signalling pathway. The E3 ubiquitin ligase TRAF6 is capable of binding to kinase-activated T $\beta R I$ in the TGF $\beta$ receptor complex, and this induces the self-ubiquitination (K63) of TRAF6. ${ }^{31} 32$ The ubiquitinated TRAF6, in turn, interacts with TAK1 and induces its K63 ubiquitination, activating its MAP kinase activity and thus resulting in downstream activation of JNK and p38 MAP kinase. (This signalling pathway is homologous to TRAF-dependent interleukin (IL)-1-mediated activation of these MAP kinases.)

TGF $\beta$-induced activation of ERK1/2 is mediated by ShcA. ${ }^{33}$ T $\beta R I$ in the activated TGF $\beta$ receptor possesses rather weak tyrosine kinase activity; this enables its tyrosine autophosphorylation, inducing binding of ShcA. T $\beta R I$ then tyrosine phosphorylates ShcA, which can then bind Grb2/Sos to stimulate GTP binding to Ras. Activated Ras, via the canonical Raf-MEK pathway, induces ERK1/2 activation.

Activated ERK1/2, JNK and p38 MAP kinase can collaborate to boost c-Fos expression and confer a serine phosphorylation on c-Jun which boosts its transactivational activity. ${ }^{34}$ As a result, AP-1 activity is markedly induced, and this collaborates with Smad2/3Smad4 heterodimers to promote TGF $\beta$-mediated transcription. One of the genes whose 
transcription is induced in this manner codes for NOX4, which constitutively generates superoxide/hydrogen peroxide. ${ }^{35}$ NOX 4 induction plays a key role in upregulating TGF $\beta$ signalling, as inhibitors of this enzyme notably blunt TGF $\beta$ activity. ${ }^{136-38}$ This is at least partially attributable to the fact that nuclear NOX4 generates hydrogen peroxide which reversibly inhibits MAP kinase phosphatase-1. ${ }^{39}$ This latter enzyme functions to deactivate both JNK and p38 MAP kinase; its inactivation by NOX4 hence upregulates JNK and p38 activation, thereby boosting the TGF $\beta$ signal. NOX4-mediated inhibition of tyrosine phosphatase activity (such as PTP1B) may also contribute to NOX4's impact on TGF $\beta$ signalling. ${ }^{40} 41$

\section{CGMP, OESTROGEN RECEPTOR-B, NRF2, SIRT1 AND HYDROGEN SULFIDE CAN DIMINISH TGFB SIGNALLING}

TGF $\beta$ signalling can be opposed by cGMP, the ligandbound oestrogen receptor- $\beta$ (ER $\beta$ ), activation of the nrf2 transcription factor and the Sirt1 deacetylase. The effect of cGMP in this regard is mediated by protein kinase G-1a (PKG-1a). This kinase phosphorylates the TGF $\beta$-activated Smad3 (pSmad3) in such a way as to prevent the translocation of $\mathrm{pSmad} 3 / \mathrm{Smad} 4$ heterodimers to the nucleus. ${ }^{42}{ }^{43}$ Once phosphorylated by PKG-1a, Smad3 has a high affinity for cytosolic beta2-tubulin, resulting in its sequestration in the cytoplasm. ${ }^{44}$ Other research suggests that PKG activity may interfere with TGF $\beta$ signalling by promoting the proteasomal degradation of Smad3 ${ }^{45}$ Not surprisingly, agents with boost cellular levels of cGMP have also been shown to oppose tissue fibrosis and TGF $\beta$ activity. $424346-56$

Ligand-bound activated ER $\beta$ has been found to downregulate TGF $\beta$-mediated transcription by a direct interaction with AP-1 complexes that blocks their transactivational activity. ${ }^{5758}$ This interaction does not involve binding of ER $\beta$ to oestrogen response elements on DNA, but rather to c-Jun. This may rationalise preclinical and epidemiological evidence that endogenous or therapeutic oestrogen provides protection from cardiac hypertrophy, hepatic fibrosis, glomerulosclerosis and primary open-angle glaucoma (POAG) ${ }^{59-68}$ Pertinently, ER $\beta$ is expressed in hepatic stellate cells, mesangial cells, cardiac fibroblasts and prostate stroma. ${ }^{596269-73}$ Moreover, polymorphisms of the ER $\beta$ gene (but not that of the ER $\alpha$ gene) have been linked to increased risk for POAG. ${ }^{745}$

A number of studies show that activation of the Nrf2 transcription factor, mediator of the phase II response, can suppress TGF $\beta$ signalling. ${ }^{76-81}$ Although Nrf2 has the potential to antagonise TGF $\beta$ signalling via promotion of glutathione synthesis and various antioxidant enzymesthereby opposing the upregulatory impact of Nox4produced oxidants on TGF $\beta$ activity ${ }^{80}$ - it also does so by boosting the protein level of SMAD7, which interacts with the type 1 TGF $\beta$ receptor in such a way as to block its association with SMAD2/3, and acts in additional ways to oppose SMAD-dependent TGF $\beta$ activity. ${ }^{7781} 82$ This effect of Nrf2 is indirect, reflecting its ability to decrease protein expression of SMURF1, an E3 ubiquitin ligase that targets SMAD7 for proteolytic degradation. ${ }^{77} 81$

Many studies, though not all, ${ }^{83}$ report that increased activity of the class III deacetylase Sirt1 downregulates TGF $\beta$ signalling and opposes pathological fibrosis. ${ }^{84-92}$ Conversely, TGF $\beta$ activity suppresses Sirt1 expression. ${ }^{93}$ The downregulatory effect of Sirt1 on TGF $\beta$ signalling is mediated, in part, by decreased protein expression of p300, a histone acetyltransferase which acts as a coactivator for SMAD2/3-dependent transcription; Sirt1 promotes its proteasomal degradation. ${ }^{85} 9495$ However, Sirt1 can deacetylate SMADs 2, 3 and 4, and this may also play a role in this effect. ${ }^{91} 92$

Numerous studies have demonstrated that, in vivo, exogenous hydrogen sulfide $\left(\mathrm{H}_{2} \mathrm{~S}\right)$ inhibits fibrosis in a range of tissues, and, in vitro, opposes TGF $\beta$ signalling. ${ }^{96-109}$ That this effect is of physiological significance is suggested by the fact that genetic deficiency of enzymes that generate $\mathrm{H}_{2} \mathrm{~S}$-for example, cystathione- $\beta$-synthase (CBS), cystathionine- $\gamma$-lyase (CSE) - as well as agents which inhibit expression of these enzymes, promote tissue fibrosis; moreover, expression of these enzymes is often decreased in fibrosis models. ${ }^{97100}{ }^{109-115}$ In rodent models of fibrosis and in cultured cells exposed to TGF $\beta, \mathrm{H}_{2} \mathrm{~S}$ suppresses SMAD2/3 phosphorylation and ERK activation. ${ }^{96} 97101101102116-119$ This effect may be partially attributable to decreased expression of TGF $\beta$ receptors types I and II, but the possibility that $\mathrm{H}_{2} \mathrm{~S}$ intervenes in signalling by the intact receptor cannot be ruled out. ${ }^{101} 119$ In vivo, $\mathrm{H}_{2} \mathrm{~S}$ has also been reported to decrease TGF $\beta$ expression. ${ }^{101-103105}$

\section{NUTRACEUTICALS THAT MAY DOWNREGULATE TGFB SIGNALLING}

These considerations suggest that several nutraceuticals may have potential for downregulating TGF $\beta$ activity and thereby opposing pathological fibrosis. In regard to NOX4, it may be possible to decrease its activity via administration of spirulina or of spirulina extracts enriched in phycocyanobilin (PhyCB). The latter, a metabolic derivative and close homolog of biliverdin, has been found to share the latter's ability to inhibit certain nicotinamide adenine dinucleotide phosphate (NADPH) oxidase complexes, including those dependent on NOX4. ${ }^{120} 121$ Oxidative stress, via induction of heme oxygenase-1 (HO-1), promotes generation of biliverdin from heme; this biliverdin is rapidly reduced by biliverdin reductase to yield free bilirubin, which in turn quells oxidative stress by inhibiting NADPH oxidase complexes. ${ }^{122-126} \mathrm{PhyCB}$, analogously, is reduced by biliverdin reductase to phycocyanorubin, a homolog of bilirubin that shares its ability to inhibit these complexes. ${ }^{127}$ This likely explains, in large part, why oral administration of PhyCB, spirulina or phycocyanin (the spirulina protein which contains PhyCB as a covalently attached chromophore) has exerted profound antioxidant/ anti-inflammatory activity in rodents in a wide variety 
of contexts. ${ }^{120} 128129$ In particular, oral administration of spirulina/PhyCB has been shown to inhibit induction of hepatic, pulmonary and oral fibrosis, as well as glomerulosclerosis, in rodent models. ${ }^{120}{ }^{130-133}$ In vitro, exposure of two cancer cell lines to phycocyanin has been shown to inhibit TGF $\beta$-mediated epithelial-mesenchymal transition, blocking induction of type 1 collagen, vimentin, fibronectin and snail, while preserving expression of E-cadherin. ${ }^{134}$

Phase II-inducing compounds activate the Nrf2 transcription factor to boost expression of a range of antioxidant enzymes; these include HO-1, which can oppose NADPH oxidase activity by giving rise to intracellular bilirubin via the heme catabolite biliverdin. These agents also oppose or reverse the modulatory impact of hydrogen peroxide on cellular signalling by increasing glutathione synthesis and boosting the expression of a range of antioxidant enzymes. ${ }^{135-138}$ Moreover, they oppose TGF $\beta$ signalling by boosting SMAD7 levels. Perhaps the most clinically tested phase II inducer is the physiologically essential cofactor lipoic acid. ${ }^{139-143}$ Indeed, a number of studies have reported that administration of lipoic acid can oppose TGF $\beta$ signalling and induction of pathological fibrosis in various rodent models. The utility of lipoic acid in this regard has been reported for fibrosis induced by radiation, bleomycin, laminectomy, abdominal incisions and trabeculectomy; for hepatic fibrosis induced by carbon tetrachloride, thioacetamide and bile duct ligation; and for cardiac fibrosis induced by diabetes. ${ }^{14-154}$ Another natural agent with good clinical potential as a phase II inducer is ferulic acid, a compound widely distributed in plant foods, in free or bound form-and also long employed, as the sodium salt, for cardiovascular protection in Chinese medicine. ${ }^{155}$ This agent has likewise shown anti-fibrotic activity in rodent studies. ${ }^{156-159}$ Also clinically useful for phase II induction are broccoli sprout extracts, a rich, bioavailable source of the phase II inducer sulforaphane; these have been shown to exert anti-fibrotic activity in various rodent models. ${ }^{160-164}$ Moreover, in cell culture studies, sulforaphane attenuates TFG $\beta$ signalling. ${ }^{165} 166$

The neurohormone melatonin, commonly employed as a nutraceutical sleep aid, can upregulate phase II induction by boosting expression of Nrf2 at the transcriptional level. ${ }^{167-169}$ This, in turn, may reflect increased expression of the clock protein transcription factor Bmall, which drives transcription of the Nrf2 gene. ${ }^{170}{ }^{171}$ However, Bmall also induces transcription of the gene coding for Sirt1. ${ }^{172}$ Melatonin has been shown to oppose TGF $\beta$ activity and fibrosis in rodent studies and cell cultures, and this effect might reflect upregulation of both Nrf2 and Sirt1. ${ }^{173-178}$

Activation of AMP-activated kinase boosts Sirt1 activity in some tissues by increasing expression of nicotinamide ribosyltransferase, rate-limiting for the synthesis of Sirt1's substrate NAD+. ${ }^{179} 180$ The phytochemical nutraceutical berberine, which activates AMPK in a matter analogous to the diabetic drug metformin, has been reported to inhibit pulmonary, cardiac, hepatic, pancreatic and renal fibrosis in rodents, likely owing to its upregulatory impact on Sirt1 activity. ${ }^{181-188}$ Its effect in this regard would likely be complementary to that of melatonin.

Although drugs in development or in use which directly activate soluble guanylate cyclase (sGC) and potentiate its responsiveness to nitric oxide have considerable potential for control of fibrotic pathologies, ${ }^{52}{ }^{189-192}$ little consideration has been paid to the fact that, in supraphysiological but well tolerated concentrations (roughly two orders of magnitude over the physiological range), the vitamin biotin can directly activate sGC. ${ }^{193-195}$ The maximum activation which biotin can achieve is twofold to threefold-as opposed to the 100-fold activation which NO can induce-which accounts for the fact that it has been well tolerated clinically in doses as high as $100 \mathrm{mg}$ three times per day. ${ }^{196} 197$ (Whether biotin potentiates response to concurrently applied NO, as do sGC activator drugs, has not been reported.) The ability of oral highdose biotin to lower blood pressure and prevent stroke in stroke-prone spontaneously hypertensive rats has been shown to reflect systemic activation of sGC. ${ }^{198}$ Favourable clinical effects of high-dose biotin on diabetes control may reflect biotin's impact on sGC. ${ }^{199}$

Boosting NO synthesis in tissues threatened by fibrosis could also increase cGMP production. Theoretically, uncoupling of NO synthase in such tissues could upregulate TGF $\beta$ signalling. Uncoupling mediated by asymmetric dimethylarginine (ADMA) could be offset with supplemental citrulline, whereas uncoupling reflecting oxidation of NO synthase's cofactor tetrahydrobiopterin might be reversed with high-dose folate supplementation. ${ }^{200-202}$ In this regard, supplemental citrulline is reported to impede progression of diabetic nephropathy in rodents rendered diabetic with streptozotocin, likely reflecting a role for uncoupled endothelial nitric oxide synthase (eNOS) in this syndrome. ${ }^{203}$ Indeed, elevated plasma ADMA predicts progression of kidney disease, and likely plays a pathogenic role in this regard. ${ }^{204-206}$ Uncoupling of eNOS is a mediator of diastolic dysfunction in heart failure with preserved ejection fraction; hence, citrulline and/or high-dose folate might aid prevention of cardiac fibrosis in this circumstance. ${ }^{207}$ Several studies suggest that peroxynitrite-mediated uncoupling of eNOS may play a pathogenic role in lung and pulmonary artery fibrosis associated with idiopathic pulmonary fibrosis. ${ }^{208-211}$ An elevation of serum ADMA levels has been reported in patients with advanced POAG. ${ }^{212}$

Dietary or supplemental nitrates can be converted to NO (after reduction to nitrite by oral bacteria) in tissues, particularly hypoxic tissues. ${ }^{213} 214$ Feeding of sodium nitrate or of nitrate-rich beetroot juice to diet-induced obese hypertensive rats has been shown to exert favourable effects on cardiac structure and function, including a reduction in ventricular fibrosis. ${ }^{215}$

With respect to ER $\beta$, the multiple health-protective benefits of soy isoflavones have been traced to the fact that, when these agents are ingested in nutritional (as 
opposed to pharmacological) amounts, the plasma levels of unconjugated genistein and equol that result are sufficient to achieve activation of ER $\beta$, while exerting minimal impact on ER $\alpha .^{216-220}$ For this reason, nutritional intakes of soy isoflavones can evoke the protective effects of ER $\beta$, without the ER $\alpha$-mediated feminising and pro-carcinogenic effects associated with ER $\alpha$ activation. Hence, soy isoflavone supplementation or a soy-rich diet may have potential for preventing and controlling fibrotic pathologies. Oral administration of genistein suppresses collagen synthesis by rat mesangial cells in vivo, and also inhibits cardiac hypertrophy and fibrosis induced by pressure overload or isoproterenol. ${ }^{221-223}$ Oral soy isoflavones have also provided protection from hepatic fibrosis and radiation-induced pulmonary fibrosis in rodents. ${ }^{224-227}$ A controlled study of soy isoflavone supplementation in watchful-waiting BPH showed only a trend toward benefit, but the daily dose employed $(50 \mathrm{mg})$ likely was suboptimal. ${ }^{228}$ However, a clinical evaluation of a synthetic ER $\beta$ agonist in BPH likewise had a null outcome; perhaps ER $\beta$ agonists would be more effective for prevention than for therapy of this syndrome. ${ }^{229}$

Recent studies indicate that the antihypertensive, antiatherosclerotic and brain-protective benefits of taurine administration may in large measure reflect increased expression of enzymes which synthesise $\mathrm{H}_{2} \mathrm{~S}$-namely CBS and CSE. ${ }^{230} 231$ This effect has been demonstrated to date in vascular tissues and the brain, but it may well be operative in other tissues. In light of $\mathrm{H}_{2} \mathrm{~S}$ 's ability to downregulate TGF $\beta$ activity cited above, it is notable that taurine has been shown to exert anti-fibrotic effects in a number of rodent models of fibrosis, in a range of tissue, including lungs, liver, heart, kidney, pancreas and penis. ${ }^{232-244}$ Conversely, in mice with a genetic knockout of the taurine transporter, marked cardiac fibrosis is noted. ${ }^{245}$ An economical explanation of these findings could be that taurine controls TGF $\beta$ activity by supporting endogenous $\mathrm{H}_{2} \mathrm{~S}$ generation. In any case, in light of abundant rodent data, inclusion of taurine in nutraceutical regimens intended to oppose pathological fibrosis seems appropriate, particularly as this agent is safe and inexpensive.

Tissue cysteine levels can be rate-limiting for $\mathrm{H}_{2} \mathrm{~S}$ synthesis, and those levels tend to decline in the elderly. ${ }^{246} 247$ Supplemental N-acetylcysteine (NAC) can also boost tissue levels of the key antioxidant glutathione, which can participate in mechanisms that reverse the pro-inflammatory effects of hydrogen peroxide on signalling pathways. ${ }^{248-252}$ Hence, NAC supplementation has been recommended for the elderly, and might be expected to at least modestly aid control of fibrotic syndromes in this group, both by opposing the pro-fibrotic impact of Nox4-derived hydrogen peroxide, and by enhancing $\mathrm{H}_{2} \mathrm{~S}$ synthesis. ${ }^{247} 250251$ Consistent with this speculation, oral administration of NAC has shown favourable effects in multiple rodent models of pathogenic fibrosis. ${ }^{253-267}$ Moreover, NAC also has
Box 1 Suggested dose schedules for nutraceuticals with anti-fibrotic potential in COVID-19 and other fibrotic disorders

$\mathrm{N}$-acetylcysteine $-600 \mathrm{mg}$ two times per day.

Lipoic acid-600 mg two times per day.

Ferulic acid-250 mg two times per day.

Broccoli sprout powder -5 gone to two times per day (providing

$20-40 \mathrm{mg}$ of sulforaphane).

Spirulina-15 gone time per day.

Melatonin-10 $\mathrm{mg}$ at bedtime.

Berberine $-500 \mathrm{mg}$ two times per day.

Taurine $-1 \mathrm{~g}$ two times per day.

Folate-10 $\mathrm{mg}$ two times per day.

Soy Isoflavones-75 mg two times per day.

Biotin-10 mg two times per day.

Vitamin D-4000 IU daily.

been shown to downregulate TGF $\beta$ signalling in cell cultures. ${ }^{268}$

\section{CONCLUSION}

In summary, spirulina/PhyCB, phase II inducers such as lipoic acid, ferulic acid or broccoli sprout powder, melatonin, berberine, high-dose biotin, soy isoflavones, taurine and NAC may have potential for downregulating TGF $\beta$ signalling, and thereby decreasing risk for, or improving clinical control of, a wide range of pro-fibrotic pathologies. Suggested dose schedules for these agents are presented in box 1. With regard to post-COVID-19 syndrome specifically, the antioxidant/anti-inflammatory effects of PhyCB, phase II inducers, melatonin and NAC might address neurological aspects of this syndrome thought likely to reflect chronic inflammation of cerebrovascular endothelial cells and microglia. ${ }^{269-272}$ Further studies are needed to confirm the benefit and safety of this potential nutraceutical strategy in COVID-19.

\section{Contributors All authors contributed to the final manuscript.}

Funding The authors have not declared a specific grant for this research from any funding agency in the public, commercial or not-for-profit sectors.

Competing interests JJD is Director of Scientific Affairs for Advanced Ingredients for Dietary Products. MM is coinventor and co-owner of US and EU patents pertaining to nutraceutical/pharmaceutical uses of phycocyanobilin oligopeptides extracted from food algae such as spirulina and owns a nutraceutical company. J0 is an owner of a nutraceutical company.

Patient consent for publication Not required.

Provenance and peer review Not commissioned; internally peer reviewed.

Open access This is an open access article distributed in accordance with the Creative Commons Attribution Non Commercial (CC BY-NC 4.0) license, which permits others to distribute, remix, adapt, build upon this work non-commercially, and license their derivative works on different terms, provided the original work is properly cited, appropriate credit is given, any changes made indicated, and the use is non-commercial. See: http://creativecommons.org/licenses/by-nc/4.0/.

\section{ORCID iDs}

James J DiNicolantonio http://orcid.org/0000-0002-7888-1528

James H O'Keefe http://orcid.org/0000-0002-3376-5822 


\section{REFERENCES}

1 Sampson N, Koziel R, Zenzmaier C, et al. Ros signaling by Nox4 drives fibroblast-to-myofibroblast differentiation in the diseased prostatic stroma. Mol Endocrinol 2011;25:503-15.

2 Mori H, Maki M, Oishi K, et al. Increased expression of genes for basic fibroblast growth factor and transforming growth factor type beta 2 in human benign prostatic hyperplasia. Prostate 1990;16:71-80.

3 Wang L, Xie L, Tintani F, et al. Aberrant transforming growth factor- $\beta$ activation recruits mesenchymal stem cells during prostatic hyperplasia. Stem Cells Trans/ Med 2017;6:394-404.

4 Alonso-Magdalena P, Brössner C, Reiner A, et al. A role for epithelial-mesenchymal transition in the etiology of benign prostatic hyperplasia. Proc Natl Acad Sci U S A 2009;106:2859-63.

5 Verrecchia F, Mauviel A, Farge D. Transforming growth factor- $\beta$ signaling through the Smad proteins: role in systemic sclerosis. Autoimmun Rev 2006;5:563-9.

$6 \mathrm{Ihn} \mathrm{H}$. Autocrine TGF-beta signaling in the pathogenesis of systemic sclerosis. J Dermatol Sci 2008;49:103-13.

7 Varga J, Whitfield ML. Transforming growth factor-beta in systemic sclerosis (scleroderma). Front Biosci 2009;1:226-35.

8 Goodwin A, Jenkins G. Role of integrin-mediated TGF $\beta$ activation in the pathogenesis of pulmonary fibrosis. Biochem Soc Trans 2009;37:849-54

9 Gharaee-Kermani M, Hu B, Phan SH, et al. Recent advances in molecular targets and treatment of idiopathic pulmonary fibrosis: focus on TGFbeta signaling and the myofibroblast. Curr Med Chem 2009;16:1400-17.

10 Loeffler I, Wolf G. Transforming growth factor- and the progression of renal disease. Nephrology Dialysis Transplantation 2014;29:i37-45.

11 López-Hernández FJ, López-Novoa JM. Role of TGF- $\beta$ in chronic kidney disease: an integration of tubular, glomerular and vascular effects. Cell Tissue Res 2012;347:141-54.

12 Brenner DA. Molecular pathogenesis of liver fibrosis. Trans Am Clin Climatol Assoc 2009;120:361-8.

13 Liu X, Hu H, Yin JQ. Therapeutic strategies against TGF- $\beta$ signaling pathway in hepatic fibrosis. Liver Int 2006;26:8-22.

14 Lijnen PJ, Petrov VV, Fagard RH. Induction of cardiac fibrosis by transforming growth factor- $\beta 1$. Mol Genet Metab 2000;71:418-35.

$15 \mathrm{Lim} \mathrm{H}$, Zhu YZ. Role of transforming growth factor- $\beta$ in the progression of heart failure. Cell Mol Life Sci 2006;63:2584-96.

16 Creemers EE, Pinto YM. Molecular mechanisms that control interstitial fibrosis in the pressure-overloaded heart. Cardiovasc Res 2011;89:265-72.

17 Taylor AW. Primary open-angle glaucoma: a transforming growth factor-beta pathway-mediated disease. Am J Pathol 2012;180:2201-4.

18 Zhavoronkov A, Izumchenko E, Kanherkar RR, et al. Pro-Fibrotic pathway activation in trabecular meshwork and lamina cribrosa is the main driving force of glaucoma. Cell Cycle 2016;15:1643-52.

19 El-Sakka Al, Hassoba HM, Pillarisetty RJ, et al. Peyronie's disease is associated with an increase in transforming growth factor-beta protein expression. J Urol 1997;158:1391-4.

20 Haag SM, Hauck EW, Szardening-Kirchner C, et al. Alterations in the transforming growth factor (TGF)-beta pathway as a potential factor in the pathogenesis of Peyronie's disease. Eur Urol 2007;51:255-61.

21 Zhang C, Wu Z, Li J-W, Li Jia-Wen, et al. Discharge may not be the end of treatment: pay attention to pulmonary fibrosis caused by severe COVID-19. J Med Virol 2021;93:1378-86.

22 Ahmad Alhiyari M, Ata F, Islam Alghizzawi M, Ahmad AM, Islam AM, et al. Post COVID-19 fibrosis, an emerging complicationof SARSCoV-2 infection. IDCases 2021;23:e01041.

23 Zhang Y, Feng XH, Derynck R. Smad3 and Smad4 cooperate with c-Jun/c-Fos to mediate TGF- $\beta$-induced transcription. Nature 1998;394:909-13.

24 Verrecchia F, Vindevoghel L, Lechleider RJ, et al. Smad3/AP-1 interactions control transcriptional responses to TGF- $\beta$ in a promoter-specific manner. Oncogene 2001;20:3332-40.

25 Rodríguez-Pascual F, Redondo-Horcajo M, Lamas S. Functional cooperation between Smad proteins and activator protein-1 regulates transforming growth factor-beta-mediated induction of endothelin-1 expression. Circ Res 2003;92:1288-95.

26 Kantola AK, Keski-Oja J, Koli K. Induction of human LTBP-3 promoter activity by TGF- $\beta 1$ is mediated by Smad3/4 and AP-1 binding elements. Gene 2005;363:142-50.

27 Liberati NT, Datto MB, Frederick JP, et al. Smads bind directly to the Jun family of AP-1 transcription factors. Proc Natl Acad Sci U S A 1999;96:4844-9.
28 Brodin G, Ahgren A, ten Dijke P, et al. Efficient TGF-beta induction of the Smad7 gene requires cooperation between AP-1, Sp1, and Smad proteins on the mouse Smad7 promoter. J Biol Chem 2000;275:29023-30.

29 Mu Y, Gudey SK, Landström M. Non-Smad signaling pathways. Cell Tissue Res 2012;347:11-20.

30 Guo B, Inoki K, Isono M, et al. MAPK/AP-1-dependent regulation of $\mathrm{PAl}-1$ gene expression by TGF-beta in rat mesangial cells. Kidney Int 2005;68:972-84.

31 Yamashita M, Fatyol K, Jin C, et al. Traf6 mediates Smadindependent activation of JNK and p38 by TGF-beta. Mol Cell 2008;31:918-24.

32 Sorrentino A, Thakur N, Grimsby S, et al. The type I TGF- $\beta$ receptor engages TRAF6 to activate TAK1 in a receptor kinase-independent manner. Nat Cell Biol 2008;10:1199-207.

33 Lee MK, Pardoux C, Hall MC, et al. TGF- $\beta$ activates ERK MAP kinase signalling through direct phosphorylation of ShcA. Embo J 2007;26:3957-67

34 Karin $\mathrm{M}$. The regulation of AP-1 activity by mitogen-activated protein kinases. J Biol Chem 1995;270:16483-6.

35 Bai G, Hock TD, Logsdon N, et al. A far-upstream AP-1/Smad binding box regulates human Nox4 promoter activation by transforming growth factor- $\beta$. Gene 2014;540:62-7.

36 Chan EC, Peshavariya HM, Liu G-S, et al. Nox4 modulates collagen production stimulated by transforming growth factor $\beta 1$ in vivo and in vitro. Biochem Biophys Res Commun 2013;430:918-25.

37 Jiang F, Liu G-S, Dusting GJ, et al. Nadph oxidase-dependent redox signaling in TGF- $\beta$-mediated fibrotic responses. Redox Biol 2014;2:267-72.

38 Sampson N, Berger P, Zenzmaier C. Therapeutic targeting of redox signaling in myofibroblast differentiation and age-related fibrotic disease. Oxid Med Cell Longev 2012;2012:458276

39 Liu R-M, Choi J, Wu J-H, et al. Oxidative modification of nuclear mitogen-activated protein kinase phosphatase 1 is involved in transforming growth factor beta1-induced expression of plasminogen activator inhibitor 1 in fibroblasts. J Biol Chem 2010;285:16239-47.

40 Hiraga R, Kato M, Miyagawa S, et al. Nox4-derived ROS signaling contributes to TGF-beta-induced epithelial-mesenchymal transition in pancreatic cancer cells. Anticancer Res 2013;33:4431-8.

41 Yan F, Wang Y, Wu X, et al. Nox4 and redox signaling mediate TGFbeta-induced endothelial cell apoptosis and phenotypic switch. Cell Death Dis 2014;5:e1010.

42 Li P, Oparil S, Novak L, et al. Anp signaling inhibits TGF- $\beta$-induced Smad2 and Smad3 nuclear translocation and extracellular matrix expression in rat pulmonary arterial smooth muscle cells. $J$ Appl Physiol 2007;102:390-8.

43 Li P, Wang D, Lucas J, et al. Atrial natriuretic peptide inhibits transforming growth factor $\beta$-induced Smad signaling and myofibroblast transformation in mouse cardiac fibroblasts. Circ Res 2008;102:185-92.

44 Gong K, Xing D, Li P, et al. cGMP inhibits TGF-beta signaling by sequestering Smad3 with cytosolic beta2-tubulin in pulmonary artery smooth muscle cells. Mol Endocrinol 2011;25:1794-803.

45 Saura M, Zaragoza C, Herranz B, et al. Nitric oxide regulates transforming growth factor- $\beta$ signaling in endothelial cells. Circ Res 2005;97:1115-23.

46 Yildirim A, Ersoy Y, Ercan F, et al. Phosphodiesterase-5 inhibition by sildenafil citrate in a rat model of bleomycin-induced lung fibrosis. Pulm Pharmacol Ther 2010;23:215-21.

47 Vandenwijngaert S, Pokreisz $\mathrm{P}$, Hermans $\mathrm{H}$, et al. Increased cardiac myocyte PDE5 levels in human and murine pressure overload hypertrophy contribute to adverse LV remodeling. PLoS One 2013;8:e58841

48 Patrucco E, Domes K, Sbroggió M, et al. Roles of cGMPdependent protein kinase I (cGKI) and PDE5 in the regulation of Ang Il-induced cardiac hypertrophy and fibrosis. Proc Natl Acad Sci U S A 2014;111:12925-9.

49 Higuchi T, Kawaguchi Y, Takagi K, et al. Sildenafil attenuates the fibrotic phenotype of skin fibroblasts in patients with systemic sclerosis. Clin Immunol 2015;161:333-8.

50 Zenzmaier C, Kern J, Heitz M, et al. Activators and stimulators of soluble guanylate cyclase counteract myofibroblast differentiation of prostatic and dermal stromal cells. Exp Cell Res 2015;338:162-9.

51 Mátyás C, Németh BT, Oláh A, et al. The soluble guanylate cyclase activator cinaciguat prevents cardiac dysfunction in a rat model of type-1 diabetes mellitus. Cardiovasc Diabetol 2015;14:145.

52 Sandner P, Berger P, Zenzmaier C. The potential of SGC modulators for the treatment of age-related fibrosis: a mini-review. Gerontology 2017;63:216-27. 
53 Schinner E, Wetzl V, Schramm A, et al. Inhibition of the TGF $\beta$ signalling pathway by cGMP and cGMP-dependent kinase I in renal fibrosis. FEBS Open Bio 2017;7:550-61.

54 Kasama S, Furuya M, Toyama T, et al. Effect of atrial natriuretic peptide on left ventricular remodelling in patients with acute myocardial infarction. Eur Heart J 2008;29:1485-94.

55 Nishikimi T, Inaba-lemura C, Ishimura K, et al. Natriuretic peptide/ natriuretic peptide receptor-A (NPR-A) system has inhibitory effects in renal fibrosis in mice. Regul Pept 2009;154:44-53.

56 Das S, Au E, Krazit ST, et al. Targeted disruption of guanylyl cyclase-A/natriuretic peptide receptor-A gene provokes renal fibrosis and remodeling in null mutant mice: role of proinflammatory cytokines. Endocrinology 2010;151:5841-50.

57 Cherlet T, Murphy LC. Estrogen receptors inhibit Smad3 transcriptional activity through AP-1 transcription factors. Mol Cell Biochem 2007;306:33-42.

58 Paech K, Webb P, Kuiper GG, et al. Differential ligand activation of estrogen receptors ERalpha and ERbeta at AP1 sites. Science 1997;277:1508-10.

59 Pedram A, Razandi M, Narayanan R, et al. Estrogen receptor beta signals to inhibition of cardiac fibrosis. Mol Cell Endocrinol 2016;434:57-68

60 lorga A, Li J, Sharma S, et al. Rescue of pressure overloadinduced heart failure by estrogen therapy. J Am Heart Assoc 2016;5. doi:10.1161/JAHA.115.002482. [Epub ahead of print: 22 Jan 2016].

61 Schuster I, Mahmoodzadeh S, Dworatzek E, et al. CardiomyocyteSpecific overexpression of oestrogen receptor $\beta$ improves survival and cardiac function after myocardial infarction in female and male mice. Clin Sci 2016;130:365-76.

62 Pedram A, Razandi M, O'Mahony F, et al. Estrogen receptor- $\beta$ prevents cardiac fibrosis. Mol Endocrinol 2010;24:2152-65.

63 Fliegner D, Schubert C, Penkalla A, et al. Female sex and estrogen receptor- $\beta$ attenuate cardiac remodeling and apoptosis in pressure overload. Am J Physiol Regul Integr Comp Physiol 2010;298:R1597-606.

64 Neugarten J, Golestaneh L. Gender and the prevalence and progression of renal disease. Adv Chronic Kidney Dis 2013;20:390-5.

65 Skavdahl M, Steenbergen C, Clark J, et al. Estrogen receptor- $\beta$ mediates male-female differences in the development of pressure overload hypertrophy. Am J Physiol Heart Circ Physiol 2005;288:H469-76.

66 Shimizu I. Impact of oestrogens on the progression of liver disease. Liver Int 2003;23:63-9.

$67 \mathrm{Xu} \mathrm{J-W}$, Gong J, Chang X-M, et al. Estrogen reduces CCl4- induced liver fibrosis in rats. World J Gastroenterol 2002;8:883-7.

68 Dewundara SS, Wiggs JL, Sullivan DA, et al. Is estrogen a therapeutic target for glaucoma? Semin Ophthalmol 2016;31:140-6.

69 Zhou Y, Shimizu I, Lu G, et al. Hepatic stellate cells contain the functional estrogen receptor $\beta$ but not the estrogen receptor $\alpha$ in male and female rats. Biochem Biophys Res Commun 2001;286:1059-65.

70 Potier M, Elliot SJ, Tack I, et al. Expression and regulation of estrogen receptors in mesangial cells: influence on matrix metalloproteinase-9. J Am Soc Nephrol 2001;12:241-51.

71 Daniels G, Gellert LL, Melamed J, et al. Decreased expression of stromal estrogen receptor $\alpha$ and $\beta$ in prostate cancer. Am J Trans Res 2014;6:140-6.

72 Ho CKM, Nanda J, Chapman KE, et al. Oestrogen and benign prostatic hyperplasia: effects on stromal cell proliferation and local formation from androgen. J Endocrinol 2008;197:483-91.

73 Tsurusaki T, Aoki D, Kanetake $\mathrm{H}$, et al. Zone-dependent expression of estrogen receptors $\alpha$ and $\beta$ in human benign prostatic hyperplasia. J Clin Endocrinol Metab 2003;88:1333-40.

74 Mabuchi F, Sakurada Y, Kashiwagi K, et al. Estrogen receptor beta gene polymorphism and intraocular pressure elevation in female patients with primary open-angle glaucoma. Am J Ophthalmol 2010;149:826-30.

75 de Voogd S, Wolfs RCW, Jansonius NM, et al. Estrogen receptors alpha and beta and the risk of open-angle glaucoma: the Rotterdam study. Arch Ophthalmol 2008;126:110-4.

76 Oh CJ, Kim J-Y, Min A-K, et al. Sulforaphane attenuates hepatic fibrosis via NF-E2-related factor 2-mediated inhibition of transforming growth factor- $\beta / S M A D$ signaling. Free Radic Biol Med 2012;52:671-82

77 Ryoo I-G, Ha H, Kwak M-K. Inhibitory role of the Keap1-Nrf2 pathway in TGF $\beta 1$-stimulated renal epithelial transition to fibroblastic cells: a modulatory effect on Smad signaling. PLoS One 2014;9:e93265.
78 Wang Y, Liu N, Su X, et al. Epigallocatechin-3-Gallate attenuates transforming growth factor- $\beta 1$ induced epithelial-mesenchymal transition via Nrf2 regulation in renal tubular epithelial cells. Biomed Pharmacother 2015;70:260-7.

79 Sun C, Li S, Li D. Sulforaphane mitigates muscle fibrosis in $m d x$ mice via Nrf2-mediated inhibition of TGF- $\beta / S m a d$ signaling. J Appl Physiol 2016;120:377-90.

80 Guan Y, Tan Y, Liu W, et al. Nf-E2-Related factor 2 suppresses intestinal fibrosis by inhibiting reactive oxygen species-dependent TGF- $\beta 1 /$ SMADs pathway. Dig Dis Sci 2018;63:366-80.

81 Song M-K, Lee J-H, Ryoo I-G, et al. Bardoxolone ameliorates TGF$\beta 1$-associated renal fibrosis through Nrf2/Smad7 elevation. Free Radic Biol Med 2019;138:33-42.

82 Yan X, Liu Z, Chen Y. Regulation of TGF-beta signaling by Smad7. Acta Biochim Biophys Sin 2009;41:263-72.

83 Zerr P, Palumbo-Zerr K, Huang J, et al. Sirt1 regulates canonical TGF- $\beta$ signalling to control fibroblast activation and tissue fibrosis. Ann Rheum Dis 2016;75:226-33.

84 Huang $X-Z$, Wen D, Zhang $M$, et al. Sirt1 activation ameliorates renal fibrosis by inhibiting the TGF- $\beta / S m a d 3$ pathway. $J$ Cell Biochem 2014;115:996-1005.

85 Wei J, Ghosh AK, Chu H, et al. The histone deacetylase sirtuin 1 is reduced in systemic sclerosis and abrogates fibrotic responses by targeting transforming growth factor $\beta$ signaling. Arthritis Rheumatol 2015;67:1323-34.

86 Cappetta D, Esposito G, Piegari E, et al. Sirt1 activation attenuates diastolic dysfunction by reducing cardiac fibrosis in a model of anthracycline cardiomyopathy. Int $J$ Cardiol 2016;205:99-110.

87 Zhang Y, Connelly KA, Thai K, et al. Sirtuin 1 activation reduces transforming growth factor- $\beta 1$-induced fibrogenesis and affords organ protection in a model of progressive, experimental kidney and associated cardiac disease. Am J Pathol 2017;187:80-90.

88 Chu H, Jiang S, Liu Q, et al. Sirtuin1 protects against systemic sclerosis-related pulmonary fibrosis by decreasing proinflammatory and profibrotic processes. Am J Respir Cell Mol Biol 2018;58:28-39

89 Xue M, Li Y, Hu F, et al. High glucose up-regulates microRNA-34a$5 \mathrm{p}$ to aggravate fibrosis by targeting SIRT1 in HK-2 cells. Biochem Biophys Res Commun 2018;498:38-44.

90 García-Vizcaíno EM, Liarte S, Alonso-Romero JL, et al. Sirt1 interaction with active Smad2 modulates transforming growth factor- $\beta$ regulated transcription. Cell Commun Signal 2017;15:50.

91 Li Z, Wang F, Zha S, et al. Sirt1 inhibits TGF- $\beta$-induced endothelialmesenchymal transition in human endothelial cells with Smad4 deacetylation. J Cell Physiol 2018;233:9007-14.

92 Bugyei-Twum A, Ford C, Civitarese R, et al. Sirtuin 1 activation attenuates cardiac fibrosis in a rodent pressure overload model by modifying Smad2/3 transactivation. Cardiovasc Res 2018;114:1629-41.

93 XU YAO, Wang S, Tang C, et al. Upregulation of long non-coding RNA HIF $1 \alpha$-anti-sense 1 induced by transforming growth factor- $\beta$-mediated targeting of sirtuin 1 promotes osteoblastic differentiation of human bone marrow stromal cells. Mol Med Rep 2015;12:7233-8.

94 Zeng $\mathrm{Z}$, Cheng $\mathrm{S}$, Chen $\mathrm{H}$, et al. Activation and overexpression of SIRT1 attenuates lung fibrosis via p300. Biochem Biophys Res Commun 2017;486:1021-6.

95 Kuno A, Hori YS, Hosoda R, et al. Resveratrol improves cardiomyopathy in dystrophin-deficient mice through SIRT1 protein-mediated modulation of p300 protein. J Biol Chem 2013;288:5963-72.

96 Bai Y-W, Ye M-J, Yang D-L, et al. Hydrogen sulfide attenuates paraquat-induced epithelial-mesenchymal transition of human alveolar epithelial cells through regulating transforming growth factor- $\beta 1 / \mathrm{Smad} 2 / 3$ signaling pathway. J Appl Toxicol 2019;39:432-40.

97 Fang L-P, Lin Q, Tang C-S, et al. Hydrogen sulfide attenuates epithelial-mesenchymal transition of human alveolar epithelial cells. Pharmacol Res 2010;61:298-305.

98 Yuan P, Xue H, Zhou L, et al. Rescue of mesangial cells from high glucose-induced over-proliferation and extracellular matrix secretion by hydrogen sulfide. Nephrol Dial Transplant 2011;26:2119-26.

99 Shen Q, Qin Z, Lu A. [Preventive effect of exogenous hydrogen sulfide on hepatic fibrosis in rats]. Zhong Nan Da Xue Xue Bao Yi Xue Ban 2012;37:911-5.

100 Song K, Wang F, Li Q, et al. Hydrogen sulfide inhibits the renal fibrosis of obstructive nephropathy. Kidney Int 2014;85:1318-29.

101 Sun L, Jin H, Sun L, et al. Hydrogen sulfide alleviates myocardial collagen remodeling in association with inhibition of TGF- $\beta / S$ mad 
signaling pathway in spontaneously hypertensive rats. Mol Med 2014;20:503-15.

102 Meng G, Zhu J, Xiao Y. Hydrogen sulfide donor GYY4137 protects against myocardial fibrosis. Oxid Med Cell Longev 2015;2015:691070.

103 Zhang Y, Wang J, Li H, et al. Hydrogen sulfide suppresses transforming growth factor- $\beta 1$-induced differentiation of human cardiac fibroblasts into myofibroblasts. Sci China Life Sci 2015:58:1126-34.

104 Liao C-C, Chen Y-H, Lin F, et al. Hydrogen sulfide inhibits transforming growth factor beta-1 induced bronchial epithelialmesenchymal transition. Chin Med J 2015;128:3247-50.

$105 \mathrm{Li} \mathrm{Y,} \mathrm{Li} \mathrm{L,} \mathrm{Zeng} \mathrm{O,} \mathrm{et} \mathrm{al.} \mathrm{H}_{2} \mathrm{~S}$ improves renal fibrosis in STZinduced diabetic rats by ameliorating TGF- $\beta 1$ expression. Ren Fail 2017;39:265-72.

106 Lin S, Juriasingani S, Sener A. Is hydrogen sulfide a potential novel therapy to prevent renal damage during ureteral obstruction? Nitric Oxide 2018;73:15-21.

107 Liu M, Li Y, Liang B, et al. Hydrogen sulfide attenuates myocardial fibrosis in diabetic rats through the JAK/STAT signaling pathway. Int $\mathrm{J}$ Mol Med 2018;41:1867-76.

108 Racine M, Fu M, Shuang T, et al. Reversal of Sp1 transactivation and TGF $\beta 1 / \mathrm{SMAD} 1$ signaling by $\mathrm{H}_{2} \mathrm{~S}$ prevent nickel-induced fibroblast activation. Toxicol Appl Pharmacol 2018;356:25-35.

109 Zhang S, Pan C, Zhou F, et al. Hydrogen sulfide as a potential therapeutic target in fibrosis. Oxid Med Cell Longev 2015;2015:593407

110 Robert K, Nehmé J, Bourdon E, et al. Cystathionine $\beta$ synthase deficiency promotes oxidative stress, fibrosis, and steatosis in mice liver. Gastroenterology 2005;128:1405-15.

111 Hamelet J, Maurin N, Fulchiron R, et al. Mice lacking cystathionine beta synthase have lung fibrosis and air space enlargement. Exp Mol Pathol 2007;83:249-53.

112 Yuan X, Zhang J, Xie F, et al. Loss of the protein cystathionine $\beta$-synthase during kidney injury promotes renal tubulointerstitial fibrosis. Kidney Blood Press Res 2017;42:428-43.

113 Ci L, Yang X, Gu X, et al. Cystathionine $\gamma$-Lyase Deficiency Exacerbates $\mathrm{CCl}$-Induced Acute Hepatitis and Fibrosis in the Mouse Liver. Antioxid Redox Signal 2017;27:133-49.

114 Han SJ, Noh MR, Jung J-M, et al. Hydrogen sulfide-producing cystathionine $\gamma$-lyase is critical in the progression of kidney fibrosis. Free Radic Biol Med 2017;112:423-32.

115 Fang L, Li H, Tang C, et al. Hydrogen sulfide attenuates the pathogenesis of pulmonary fibrosis induced by bleomycin in rats. Can J Physiol Pharmacol 2009;87:531-8.

116 Wang Z, Yin X, Gao L, et al. The protective effect of hydrogen sulfide on systemic sclerosis associated skin and lung fibrosis in mice model. Springerplus 2016;5:1084.

117 Jung K-J, Jang H-S, Kim Jl, et al. Involvement of hydrogen sulfide and homocysteine transsulfuration pathway in the progression of kidney fibrosis after ureteral obstruction. Biochim Biophys Acta 2013;1832:1989-97.

118 Cheng S, Lu Y, Li Y, et al. Hydrogen sulfide inhibits epithelialmesenchymal transition in peritoneal mesothelial cells. Sci Rep 2018;8:5863

119 Yang R, Jia Q, Ma S-F, et al. Exogenous H2S mitigates myocardial fibrosis in diabetic rats through suppression of the canonical Wnt pathway. Int J Mol Med 2019;44:549-58.

120 McCarty MF. Clinical potential of Spirulina as a source of phycocyanobilin. J Med Food 2007;10:566-70.

121 Zheng J, Inoguchi T, Sasaki S, et al. Phycocyanin and phycocyanobilin from Spirulina platensis protect against diabetic nephropathy by inhibiting oxidative stress. Am J Physiol Regul Integr Comp Physiol 2013;304:R110-20.

122 Lanone S, Bloc S, Foresti R, et al. Bilirubin decreases nos2 expression via inhibition of $\mathrm{NAD}(\mathrm{P}) \mathrm{H}$ oxidase: implications for protection against endotoxic shock in rats. FASEB j. 2005;19:1890-2.

123 Matsumoto H, Ishikawa K, Itabe $\mathrm{H}$, et al. Carbon monoxide and bilirubin from heme oxygenase-1 suppresses reactive oxygen species generation and plasminogen activator inhibitor-1 induction. Mol Cell Biochem 2006;291:21-8.

124 Jiang F, Roberts SJ, Datla Sraju, Datla S, et al. NO modulates NADPH oxidase function via heme oxygenase- 1 in human endothelial cells. Hypertension 2006;48:950-7.

125 Datla SR, Dusting GJ, Mori TA, et al. Induction of heme oxygenase-1 in vivo suppresses NADPH Oxidase-Derived oxidative stress. Hypertension 2007;50:636-42.

126 Basuroy S, Bhattacharya S, Leffler CW, et al. Nox4 NADPH oxidase mediates oxidative stress and apoptosis caused by TNF-alpha in cerebral vascular endothelial cells. Am J Physiol Cell Physiol 2009;296:C422-32.
127 Terry MJ, Maines MD, Lagarias JC. Inactivation of phytochromeand phycobiliprotein-chromophore precursors by rat liver biliverdin reductase. Journal of Biological Chemistry 1993;268:26099-106.

128 Romay C, Gonzalez R, Ledon N, et al. Rimbau V. C-phycocyanin: a biliprotein with antioxidant, anti-inflammatory and neuroprotective effects. Curr Protein Pept Sci 2003;4:207-16.

129 Liu Q, Huang Y, Zhang R, et al. Medical application of Spirulina platensis derived C-phycocyanin. Evid Based Complement Alternat Med 2016;2016:7803846.

130 Huang Z, Zheng W. [Antagonistic effects of Se-rich Spirulina platensis on rat liver fibrosis]. Wei Sheng Yan Jiu 2007;36:34-6.

131 Pak W, Takayama F, Mine M, et al. Anti-oxidative and antiinflammatory effects of Spirulina on rat model of non-alcoholic steatohepatitis. J Clin Biochem Nutr 2012;51:227-34.

132 Sun Y-xin, Zhang J, Yu G-chang, et al. [Experimental study on the therapeutic effect of $\mathrm{C}$-phycocyanin against pulmonary fibrosis induced by paraquat in rats]. Zhonghua Lao Dong Wei Sheng Zhi Ye Bing Za Zhi 2012;30:650-5.

133 Shetty P, Shenai P, Chatra L, et al. Efficacy of Spirulina as an antioxidant adjuvant to corticosteroid injection in management of oral submucous fibrosis. Indian J Dent Res 2013;24:347-50.

134 Pattarayan D, Rajarajan D, Ayyanar S, et al. C-Phycocyanin suppresses transforming growth factor- $\beta 1$-induced epithelia mesenchymal transition in human epithelial cells. Pharmacol Rep 2017;69:426-31.

135 Arthur JR. The glutathione peroxidases. CMLS, Cell Mol Life Sci 2001;57:1825-35.

136 Dickinson DA, Forman HJ. Glutathione in defense and signaling: lessons from a small thiol. Ann N Y Acad Sci 2002;973:488-504

137 Shelton MD, Chock PB, Mieyal JJ. Glutaredoxin: role in reversible protein s-glutathionylation and regulation of redox signal transduction and protein translocation. Antioxid Redox Signal 2005;7:348-66.

138 Parsons ZD, Gates KS. Thiol-dependent recovery of catalytic activity from oxidized protein tyrosine phosphatases. Biochemistry 2013;52:6412-23

139 Suh JH, Shenvi SV, Dixon BM, et al. Decline in transcriptional activity of Nrf2 causes age-related loss of glutathione synthesis, which is reversible with lipoic acid. Proc Natl Acad Sci U S A 2004;101:3381-6.

140 Ogborne RM, Rushworth SA, O'Connell MA. Alpha-lipoic acidinduced heme oxygenase- 1 expression is mediated by nuclear factor erythroid 2-related factor 2 and p38 mitogen-activated protein kinase in human monocytic cells. Arterioscler Thromb Vasc Biol 2005;25:2100-5.

141 Shay KP, Moreau RF, Smith EJ, et al. Alpha-lipoic acid as a dietary supplement: molecular mechanisms and therapeutic potential. Biochim Biophys Acta 2009;1790:1149-60.

142 Lii C-K, Liu K-L, Cheng Y-P, et al. Sulforaphane and $\alpha$-lipoic acid upregulate the expression of the $\pi$ class of glutathione S-transferase through c-Jun and Nrf2 activation. J Nutr 2010;140:885-92.

143 Shay KP, Michels AJ, Li W, et al. Cap-independent Nrf2 translation is part of a lipoic acid-stimulated detoxification stress response. Biochim Biophys Acta 2012;1823:1102-9.

144 Liu R, Ahmed KM, Nantajit D, et al. Therapeutic effects of alphalipoic acid on bleomycin-induced pulmonary fibrosis in rats. Int $J$ Mol Med 2007;19:865-73.

145 Min AK, Kim M-K, Seo H-Y, et al. Alpha-lipoic acid inhibits hepatic PAI-1 expression and fibrosis by inhibiting the TGF- $\beta$ signaling pathway. Biochem Biophys Res Commun 2010;393:536-41.

146 Foo NP, Lin S-H, Lee Y-H, et al. Alpha-lipoic acid inhibits liver fibrosis through the attenuation of ROS-triggered signaling in hepatic stellate cells activated by PDGF and TGF- $\beta$. Toxicology 2011;282:39-46.

147 Ozler M, Ersoz N, Ozerhan IH, et al. The effect of alpha-lipoic acid in the prevention of peritoneal adhesions. Turk J Gastroenterol 2011;22:190-4.

148 Morsy MA, Abdalla AM, Mahmoud AM, et al. Protective effects of curcumin, $\alpha$-lipoic acid, and $\mathrm{N}$-acetylcysteine against carbon tetrachloride-induced liver fibrosis in rats. J Physiol Biochem 2012;68:29-35

149 Kaya M, Yildirim CH, Kosemehmetoglu K, et al. Alpha-lipoic acid reduces peridural fibrosis after laminectomy of lumbar vertebrae in rabbits. Acta Neurochir 2012;154:1241-5.

150 Li C-jun, Lv L, Li H, et al. Cardiac fibrosis and dysfunction in experimental diabetic cardiomyopathy are ameliorated by alphalipoic acid. Cardiovasc Diabetol 2012;11:73.

151 Lee JE, Yi C-ok, Jeon BT, et al. Alpha-Lipoic acid attenuates cardiac fibrosis in Otsuka Long-Evans Tokushima fatty rats. Cardiovasc Diabetol 2012;11:111. 
152 Ekinci M, Cagatay HH, Ceylan E, et al. Reduction of conjunctival fibrosis after trabeculectomy using topical alpha-lipoic acid in rabbit eyes. J Glaucoma 2014;23:372-9.

153 Yildirim $\mathrm{CH}$, Yucetas SC, Kaya M. Alpha-Lipoic acid inhibits peridural fibrosis following laminectomy through the inactivation of TGF-beta1, PDGF, PAI-1 and IL-6 expressions. Turk Neurosurg 2015;25:90-9.

154 Diken Allahverdi T, Allahverdi E, Yayla S, et al. Effects of alpha lipoic acid on intra-abdominal adhesion: an experimental study in a rat model. Ulus Travma Acil Cerrahi Derg 2015;21:9-14.

155 McCarty MF, Assanga SBI. Ferulic acid may target MyD88mediated pro-inflammatory signaling - implications for the health protection afforded by whole grains, anthocyanins, and coffee. Med Hypotheses 2018;118:114-20.

156 Mu M, Zuo S, Wu R-M, et al. Ferulic acid attenuates liver fibrosis and hepatic stellate cell activation via inhibition of TGF- $\beta / S$ mad signaling pathway. Drug Des Devel Ther 2018;12:4107-15

157 Kuang J, Wei X-L, Xie M. TThe Effect of Sodium Ferulate in Experimental Pulmonary Fibrosis via NALP3 Inflammasome]. Sichuan Da Xue Xue Bao Yi Xue Ban 2017;48:503-8.

158 Wei M-gang, Sun W, He W-ming, Wei MG, WM H, et al. Ferulic Acid Attenuates TGF- $\beta$ 1-Induced Renal Cellular Fibrosis in NRK-52E Cells by Inhibiting Smad/ILK/Snail Pathway. Evid Based Complement Alternat Med 2015;2015:1-7.

159 Xu T, Pan Z, Dong M, et al. Ferulic acid suppresses activation of hepatic stellate cells through ERK1/2 and Smad signaling pathways in vitro. Biochem Pharmacol 2015;93:49-58.

160 Fahey JW, Zhang Y, Talalay P. Broccoli sprouts: an exceptionally rich source of inducers of enzymes that protect against chemical carcinogens. Proc Natl Acad Sci U S A 1997;94:10367-72.

161 Fahey JW, Holtzclaw WD, Wehage SL, et al. Sulforaphane bioavailability from Glucoraphanin-Rich broccoli: control by active endogenous myrosinase. PLoS One 2015;10:e0140963.

162 Bahadoran Z, Mirmiran P, Azizi F. Potential efficacy of broccoli sprouts as a unique supplement for management of type 2 diabetes and its complications. J Med Food 2013;16:375-82.

163 Zhang Z, Wang S, Zhou S, et al. Sulforaphane prevents the development of cardiomyopathy in type 2 diabetic mice probably by reversing oxidative stress-induced inhibition of Lkb1/AMPK pathway. J Mol Cell Cardiol 2014;77:42-52.

$164 \mathrm{Xu} \mathrm{Z,} \mathrm{Wang} \mathrm{S,} \mathrm{Ji} \mathrm{H,} \mathrm{et} \mathrm{al.} \mathrm{Broccoli} \mathrm{sprout} \mathrm{extract} \mathrm{prevents} \mathrm{diabetic}$ cardiomyopathy via Nrf2 activation in db/db T2DM mice. Sci Rep 2016;6:30252.

165 Fix C, Carver-Molina A, Chakrabarti M, et al. Effects of the isothiocyanate sulforaphane on TGF- $\beta 1$-induced rat cardiac fibroblast activation and extracellular matrix interactions. J Cell Physiol 2019;234:13931-41.

166 Kyung SY, Kim DY, Yoon JY, et al. Sulforaphane attenuates pulmonary fibrosis by inhibiting the epithelial-mesenchymal transition. BMC Pharmacol Toxicol 2018;19:13.

167 Jung $\mathrm{KH}$, Hong S-W, Zheng H-M, et al. Melatonin ameliorates cerulein-induced pancreatitis by the modulation of nuclear erythroid 2-related factor 2 and nuclear factor-kappaB in rats. J Pineal Res 2010;48:239-50.

168 Tripathi DN, Jena GB. Effect of melatonin on the expression of Nrf2 and $\mathrm{NF}-\mathrm{KB}$ during cyclophosphamide-induced urinary bladder injury in rat. J Pineal Res 2010;48:324-31.

169 Crespo I, Miguel BS, Laliena A, et al. Melatonin prevents the decreased activity of antioxidant enzymes and activates nuclear erythroid 2-related factor 2 signaling in an animal model of fulminant hepatic failure of viral origin. J Pineal Res 2010;49:193-200.

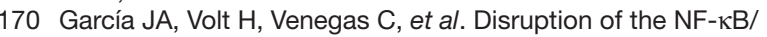
NLRP3 connection by melatonin requires retinoid-related orphan receptor- $\alpha$ and blocks the septic response in mice. Faseb $J$ 2015;29:3863-75.

171 Early JO, Menon D, Wyse CA, et al. Circadian clock protein BMAL1 regulates IL-1 $\hat{\mid}^{2}$ in macrophages via Nrf2. Proc Natl Acad Sci U S A 2018;115:E8460-8.

172 Zhou B, Zhang Y, Zhang F, et al. CLOCK/BMAL1 regulates circadian change of mouse hepatic insulin sensitivity by SIRT1. Hepatology 2014;59:2196-206.

173 Yildirim Z, Kotuk M, Erdogan H, et al. Preventive effect of melatonin on bleomycin-induced lung fibrosis in rats. J Pineal Res 2006;40:27-33.

174 Arslan SO, Zerin M, Vural H, et al. The effect of melatonin on bleomycin-induced pulmonary fibrosis in rats. J Pineal Res 2002;32:21-5.

$175 \mathrm{Hu} \mathrm{W}$, Ma Z, Jiang S, et al. Melatonin: the dawning of a treatment for fibrosis? J Pineal Res 2016;60:121-31.
176 Zhao X, Sun J, Su W, et al. Melatonin protects against lung fibrosis by regulating the Hippo/YAP pathway. Int J Mol Sci 2018;19:1118.

177 Hosseinzadeh A, Javad-Moosavi SA, Reiter RJ, et al. Idiopathic pulmonary fibrosis (IPF) signaling pathways and protective roles of melatonin. Life Sci 2018;201:17-29.

178 Shin N-R, Park J-W, Lee I-C, et al. Melatonin suppresses fibrotic responses induced by cigarette smoke via downregulation of TGF- $\beta 1$. Oncotarget 2017;8:95692-703.

179 Fulco M, Cen Y, Zhao P, et al. Glucose restriction inhibits skeletal myoblast differentiation by activating SIRT1 through AMPKmediated regulation of NAMPT. Dev Cell 2008;14:661-73.

180 Costford SR, Bajpeyi S, Pasarica M, et al. Skeletal muscle NAMPT is induced by exercise in humans. Am J Physiol Endocrinol Metab 2010;298:E117-26.

181 Lee YS, Kim WS, Kim KH, et al. Berberine, a natural plant product, activates AMP-activated protein kinase with beneficial metabolic effects in diabetic and insulin-resistant states. Diabetes 2006;55:2256-64.

182 Chitra P, Saiprasad G, Manikandan R, et al. Berberine attenuates bleomycin induced pulmonary toxicity and fibrosis via suppressing NF- $\kappa B$ dependant TGF- $\beta$ activation: a biphasic experimental study. Toxicol Lett 2013;219:178-93.

183 Wang F-M, Yang Y-J, Ma L-L, et al. Berberine ameliorates renal interstitial fibrosis induced by unilateral ureteral obstruction in rats. Nephrology 2014;19:542-51.

$184 \mathrm{Lu} \mathrm{K}$, Shen Y, He J, et al. [Berberine inhibits cardiac fibrosis of diabetic rats]. Xi Bao Yu Fen Zi Mian Yi Xue Za Zhi 2016;32:1352-5.

$185 \mathrm{Li} \mathrm{Z}$, Zhang W. Protective effect of berberine on renal fibrosis caused by diabetic nephropathy. Mol Med Rep 2017;16:1055-62.

186 Eissa LA, Kenawy HI, El-Karef A, et al. Antioxidant and antiinflammatory activities of berberine attenuate hepatic fibrosis induced by thioacetamide injection in rats. Chem Biol Interact 2018;294:91-100.

187 Che Y, Shen D-F, Wang Z-P, et al. Protective role of berberine in isoprenaline-induced cardiac fibrosis in rats. BMC Cardiovasc Disord 2019;19:219.

188 Bansod S, Doijad N, Godugu C. Berberine attenuates severity of chronic pancreatitis and fibrosis via AMPK-mediated inhibition of TGF- $\beta 1 /$ Smad signaling and M2 polarization. Toxicol App/ Pharmacol 2020;403:115162.

189 Dees C, Beyer C, Distler A, et al. Stimulators of soluble guanylate cyclase (sGC) inhibit experimental skin fibrosis of different aetiologies. Ann Rheum Dis 2015;74:1621-5.

190 Zenzmaier C, Kern J, Heitz M, et al. Activators and stimulators of soluble guanylate cyclase counteract myofibroblast differentiation of prostatic and dermal stromal cells. Exp Cell Res 2015;338:162-9.

191 Mátyás C, Németh BT, Oláh A, et al. The soluble guanylate cyclase activator cinaciguat prevents cardiac dysfunction in a rat model of type-1 diabetes mellitus. Cardiovasc Diabetol 2015;14:145

192 Schinner E, Wetzl V, Schramm A, et al. Inhibition of the TGF $\beta$ signalling pathway by cGMP and cGMP-dependent kinase I in renal fibrosis. FEBS Open Bio 2017;7:550-61.

193 Vesely D. Biotin enhances guanylate cyclase activity. Science 1982;216:1329-30.

194 Singh IN, Dakshinamurti K. Stimulation of guanylate cyclase and RNA polymerase II activities in HeLa cells and fibroblasts by biotin. Mol Cell Biochem 1988:79:47-55.

195 Vilches-Flores A, Tovar AR, Marin-Hernandez A, et al. Biotin increases glucokinase expression via soluble guanylate cyclase/ protein kinase $\mathrm{G}$, adenosine triphosphate production and autocrine action of insulin in pancreatic rat islets 2 . J Nutr Biochem 2010;21:606-12.

196 Mock DM. Biotin. In: Ziegler EE, LJJr F, eds. Present knowledge in nutrition. 7th ed. Washington,D.C: ILSI Press, 1996: 220-35

197 Tourbah A, Lebrun-Frenay C, Edan G, et al. MD1003 (high-dose biotin) for the treatment of progressive multiple sclerosis: a randomised, double-blind, placebo-controlled study. Mult Scler 2016;22:1719-31.

198 Watanabe-Kamiyama M, Kamiyama S, Horiuchi K, et al. Antihypertensive effect of biotin in stroke-prone spontaneously hypertensive rats. Br J Nutr 2008;99:756-63.

199 McCarty MF. High-Dose biotin, an inducer of glucokinase expression, may synergize with chromium picolinate to enable a definitive nutritional therapy for type II diabetes. Med Hypotheses 1999;52:401-6.

200 McCarty MF. Asymmetric dimethylarginine is a well established mediating risk factor for cardiovascular morbidity and MortalityShould patients with elevated levels be supplemented with citrulline? Healthcare 2016;4:40. 
201 Siu KL, Miao XN, Cai H. Recoupling of eNOS with folic acid prevents abdominal aortic aneurysm formation in angiotensin IIinfused apolipoprotein E null mice. PLoS One 2014;9:e88899.

202 Chalupsky K, Kračun D, Kanchev I, et al. Folic acid promotes recycling of tetrahydrobiopterin and protects against hypoxiainduced pulmonary hypertension by Recoupling endothelial nitric oxide synthase. Antioxid Redox Signal 2015;23:1076-91.

203 Romero MJ, Yao L, Sridhar S, et al. L-Citrulline protects from kidney damage in type 1 diabetic mice. Front Immunol 2013;4:480.

204 Raptis V, Kapoulas S, Grekas D. Role of asymmetrical dimethylarginine in the progression of renal disease. Nephrology 2013;18:11-21.

205 Mihout F, Shweke N, Bigé N, et al. Asymmetric dimethylarginine (ADMA) induces chronic kidney disease through a mechanism involving collagen and TGF- $\beta 1$ synthesis. J Pathol 2011;223:37-45.

206 Ueda S, Yamagishi S-ichi, Matsumoto Y, et al. Involvement of asymmetric dimethylarginine (ADMA) in glomerular capillary loss and sclerosis in a rat model of chronic kidney disease (CKD). Life Sci 2009;84:853-6.

207 Silberman GA, Fan T-HM, Liu H, et al. Uncoupled cardiac nitric oxide synthase mediates diastolic dysfunction. Circulation 2010;121:519-28.

208 Saleh D, Barnes PJ, Giaid A. Increased production of the potent oxidant peroxynitrite in the lungs of patients with idiopathic pulmonary fibrosis. Am J Respir Crit Care Med 1997;155:1763-9.

209 Vyas-Read S, Shaul PW, Yuhanna IS, et al. Nitric oxide attenuates epithelial-mesenchymal transition in alveolar epithelial cells. Am J Physiol Lung Cell Mol Physiol 2007;293:L212-21.

210 Almudéver P, Milara J, De Diego A, et al. Role of tetrahydrobiopterin in pulmonary vascular remodelling associated with pulmonary fibrosis. Thorax 2013;68:938-48.

211 Wells SM, Buford MC, Migliaccio CT, et al. Elevated asymmetric dimethylarginine alters lung function and induces collagen deposition in mice. Am J Respir Cell Mol Biol 2009;40:179-88.

212 Javadiyan S, Burdon KP, Whiting MJ, et al. Elevation of serum asymmetrical and symmetrical dimethylarginine in patients with advanced glaucoma. Invest Ophthalmol Vis Sci 2012;53:1923-7.

213 Lundberg JO, Carlström M, Larsen FJ, et al. Roles of dietary inorganic nitrate in cardiovascular health and disease. Cardiovasc Res 2011;89:525-32.

214 Machha A, Schechter AN. Inorganic nitrate: a major player in the cardiovascular health benefits of vegetables? Nutr Rev 2012;70:367-72

215 Bhaswant M, Brown L, McAinch AJ, et al. Beetroot and sodium nitrate ameliorate cardiometabolic changes in Diet-Induced obese hypertensive rats. Mol Nutr Food Res 2017;61:1700478.

216 Kuiper GG, Carlsson B, Grandien K, et al. Comparison of the ligand binding specificity and transcript tissue distribution of estrogen receptors alpha and beta. Endocrinology 1997;138:863-70.

217 Kuiper GGJM, Lemmen JG, Carlsson B, et al. Interaction of Estrogenic chemicals and phytoestrogens with estrogen receptor $\beta$. Endocrinology 1998;139:4252-63.

218 McCarty MF. Isoflavones made simple - Genistein's agonist activity for the beta-type estrogen receptor mediates their health benefits. Med Hypotheses 2006;66:1093-114.

219 Jiang Y, Gong P, Madak-Erdogan Z, et al. Mechanisms enforcing the estrogen receptor $\beta$ selectivity of botanical estrogens. FASEB $j$. 2013;27:4406-18.

220 Jackson RL, Greiwe JS, Schwen RJ. Emerging evidence of the health benefits of S-equol, an estrogen receptor $\beta$ agonist. Nutr Rev 2011:69:432-48

221 Neugarten J, Acharya A, Lei J, et al. Selective estrogen receptor modulators suppress mesangial cell collagen synthesis. Am J Physiol Renal Physiol 2000;279:F309-18.

222 Qin W, Du N, Zhang L, et al. Genistein alleviates pressure overloadinduced cardiac dysfunction and interstitial fibrosis in mice. $\mathrm{Br} \mathrm{J}$ Pharmacol 2015;172:5559-72.

223 Maulik SK, Prabhakar P, Dinda AK, et al. Genistein prevents isoproterenol-induced cardiac hypertrophy in rats. Can J Physiol Pharmacol 2012;90:1117-25.

224 Yoo N-young, Jeon S, Nam Y, et al. Dietary supplementation of genistein alleviates liver inflammation and fibrosis mediated by a methionine-choline-deficient diet in $\mathrm{db} / \mathrm{db}$ mice. J Agric Food Chem 2015;63:4305-11.

$225 \mathrm{Li}$ J-F, Chen B-C, Lai D-D, et al. Soy isoflavone delays the progression of thioacetamide-induced liver fibrosis in rats. Scand $J$ Gastroenterol 2011;46:341-9.

226 Ganai AA, Husain M. Genistein attenuates D-GalN induced liver fibrosis/chronic liver damage in rats by blocking the TGF- $\beta /$ Smad signaling pathways. Chem Biol Interact 2017;261:80-5.
227 Hillman GG, Singh-Gupta V, Lonardo F, et al. Radioprotection of lung tissue by soy isoflavones. J Thorac Oncol 2013;8:1356-64.

228 Wong WCW, Wong ELY, Li H, et al. Isoflavones in treating watchful waiting benign prostate hyperplasia: a double-blinded, randomized controlled trial. J Altern Complement Med 2012;18:54-60.

229 Roehrborn CG, Spann ME, Myers SL, et al. Estrogen receptor beta agonist LY500307 fails to improve symptoms in men with enlarged prostate secondary to benign prostatic hypertrophy. Prostate Cancer Prostatic Dis 2015:18:43-8.

230 Sun Q, Wang B, Li Y, et al. Taurine supplementation lowers blood pressure and improves vascular function in prehypertension: randomized, double-blind, placebo-controlled study. Hypertension 2016;67:541-9.

231 Zhao H, Qu J, Li Q, et al. Taurine supplementation reduces neuroinflammation and protects against white matter injury after intracerebral hemorrhage in rats. Amino Acids 2018;50:439-51.

232 Giri SN. The combined treatment with taurine and niacin blocks the bleomycin-induced activation of nuclear factor-kappaB and lung fibrosis. Adv Exp Med Biol 2003;526:381-94.

233 Sato S, Yamate J, Saito T, et al. Protective effect of taurine against renal interstitial fibrosis of rats induced by cisplatin. Naunyn Schmiedebergs Arch Pharmacol 2002;365:277-83.

234 Miyazaki T, Karube M, Matsuzaki Y, et al. Taurine inhibits oxidative damage and prevents fibrosis in carbon tetrachloride-induced hepatic fibrosis. J Hepatol 2005:43:117-25.

235 Kato Jet al. Transforming growth factor-?-induced stimulation of formation of collagen fiber network and anti-fibrotic effect of taurine in an in vitro model of hepatic fibrosis. Hepatol Res 2004;30:34-41.

236 Erman F, Balkan J, Cevikbas U, et al. Betaine or taurine administration prevents fibrosis and lipid peroxidation induced by rat liver by ethanol plus carbon tetrachloride intoxication. Amino Acids 2004;27:199-205.

237 Schuller-Levis G, Gordon RE, Wang C, et al. Protection of bleomycin-induced fibrosis and inflammation by taurine. Int Immunopharmacol 2009;9:971-7.

238 Devi SL, Viswanathan P, Anuradha CV. Taurine enhances the metabolism and detoxification of ethanol and prevents hepatic fibrosis in rats treated with iron and alcohol. Environ Toxicol Pharmacol 2009;27:120-6.

239 Shirahige A, Mizushima T, Matsushita K, et al. Oral administration of taurine improves experimental pancreatic fibrosis. J Gastroenterol Hepatol 2008;23:321-7.

240 Fallahzadeh MK, Namazi MR, Gupta RC. Taurine: a potential novel addition to the anti-systemic sclerosis weaponry. Arch Med Res 2010;41:59-61.

241 Robb WB, Condron C, Moriarty M, et al. Taurine attenuates radiation-induced lung fibrosis in C57/BI6 fibrosis prone mice. Ir J Med Sci 2010:179:99-105.

242 Matsushita K, Mizushima T, Shirahige A, et al. Effect of taurine on acinar cell apoptosis and pancreatic fibrosis in dibutyltin dichlorideinduced chronic pancreatitis. Acta Med Okayama 2012;66:329-34.

243 Yu Y-R, Ni X-Q, Huang J, et al. Taurine drinking ameliorates hepatic granuloma and fibrosis in mice infected with Schistosoma japonicum. Int J Parasitol Drugs Drug Resist 2016;6:35-43.

244 Ruan Y, Li M, Wang T, et al. Taurine supplementation improves erectile function in rats with streptozotocin-induced type 1 diabetes via amelioration of penile fibrosis and endothelial dysfunction. $J$ Sex Med 2016:13:778-85.

245 Ito T, Hanahata Y, Kine K, et al. Tissue taurine depletion induces profibrotic pattern of gene expression and causes aging-related cardiac fibrosis in heart in mice. Biol Pharm Bull 2018;41:1561-6.

246 DiNicolantonio JJ, OKeefe JH, McCarty MF. Boosting endogenous production of vasoprotective hydrogen sulfide via supplementation with taurine and $\mathrm{N}$-acetylcysteine: a novel way to promote cardiovascular health. Open Heart 2017;4:e000600.

247 Dröge W, Kinscherf R, Hildebrandt W, et al. The deficit in low molecular weight thiols as a target for antiageing therapy. Curr Drug Targets 2006;7:1505-12.

248 Atkuri KR, Mantovani JJ, Herzenberg LA, et al. N-Acetylcysteine-a safe antidote for cysteine/glutathione deficiency. Curr Opin Pharmacol 2007:7:355-9.

249 Dodd S, Dean O, Copolov DL, et al. N -acetylcysteine for antioxidant therapy: pharmacology and clinical utility. Expert Opin Biol Ther 2008:8:1955-62.

250 McCarty MF, DiNicolantonio JJ. An increased need for dietary cysteine in support of glutathione synthesis may underlie the increased risk for mortality associated with low protein intake in the elderly. Age 2015;37:96.

251 Sekhar RV, Patel SG, Guthikonda AP, et al. Deficient synthesis of glutathione underlies oxidative stress in aging and can be corrected 
by dietary cysteine and glycine supplementation. Am J Clin Nutr 2011;94:847-53.

252 Dickinson DA, Forman HJ. Glutathione in defense and signaling: lessons from a small thiol. Ann N Y Acad Sci 2002;973:488-504.

253 Shahzeidi S, Sarnstrand B, Jeffery PK, et al. Oral N-acetylcysteine reduces bleomycin-induced collagen deposition in the lungs of mice. Eur Respir J 1991;4:845-52.

254 Teixeira KC, Soares FS, Rocha LGC, et al. Attenuation of bleomycin-induced lung injury and oxidative stress by $\mathrm{N}$ acetylcysteine plus deferoxamine. Pulm Pharmacol Ther 2008;21:309-16.

255 Zhou C-F, Yu J-F, Zhang J-X, et al. N -acetylcysteine attenuates subcutaneous administration of bleomycin-induced skin fibrosis and oxidative stress in a mouse model of scleroderma. Clin Exp Dermatol 2013;38:403-9.

256 Liu C, Lu X-Z, Shen M-Z, et al. N-Acetyl cysteine improves the diabetic cardiac function: possible role of fibrosis inhibition. BMC Cardiovasc Disord 2015;15:84.

257 Shen Y, Miao N-J, Xu J-L, et al. N-Acetylcysteine alleviates angiotensin II-mediated renal fibrosis in mouse obstructed kidneys. Acta Pharmacol Sin 2016;37:637-44.

258 Giam B, Chu P-Y, Kuruppu S, et al. N-acetylcysteine attenuates the development of cardiac fibrosis and remodeling in a mouse model of heart failure. Physiol Rep 2016;4. doi:10.14814/phy2.12757. [Epub ahead of print: 13 Apr 2016].

259 Haseeb A, Bilal M, Khan MAS. N-Acetyl cysteine: a possible treatment for diabetic cardiomyopathy. J Coll Physicians Surg Pak 2016;26:720

260 Giam B, Kuruppu S, Chu P-Y, et al. N-Acetylcysteine Attenuates the Development of Renal Fibrosis in Transgenic Mice with Dilated Cardiomyopathy. Sci Rep 2017;7:17718.

261 Huang $\mathrm{H}$, Chen M, Liu F, et al. N-Acetylcysteine tiherapeutically protects against pulmonary fibrosis in a mouse model of silicosis. Biosci Rep 2019;39.
262 Cortijo J, Cerdá-Nicolás M, Serrano A, et al. Attenuation by oral Nacetylcysteine of bleomycin-induced lung injury in rats. Eur Respir J 2001;17:1228-35.

263 Pereira-Filho G, Ferreira C, Schwengber A, et al. Role of Nacetylcysteine on fibrosis and oxidative stress in cirrhotic rats. Arq Gastroenterol 2008;45:156-62.

264 Galicia-Moreno M, Rodríguez-Rivera A, Reyes-Gordillo K, et al. $\mathrm{N}$-Acetylcysteine prevents carbon tetrachloride-induced liver cirrhosis: role of liver transforming growth factor-beta and oxidative stress. Eur J Gastroenterol Hepatol 2009;21:908-14.

265 Wolters PJ. Could $N$-acetylcysteine slow progression of idiopathic pulmonary fibrosis by inhibiting EMT? Am J Physiol Lung Cell Mol Physiol 2009;297:L803-4.

266 Galicia-Moreno M, Favari L, Muriel P. Antifibrotic and antioxidant effects of $\mathrm{N}$-acetylcysteine in an experimental cholestatic model. Eur J Gastroenterol Hepatol 2012;24:179-85.

267 Zhang H, Yin G, Jiang H, et al. High-Dose N-acetylcysteine decreases silica-induced lung fibrosis in the rat. $J$ Int Med Res 2013;41:1179-86.

268 Meurer SK, Lahme B, Tihaa L, et al. N-Acetyl-L-Cysteine suppresses TGF- $\beta$ signaling at distinct molecular steps: the biochemical and biological efficacy of a multifunctional, antifibrotic drug. Biochem Pharmacol 2005;70:1026-34.

269 Jiang Y, Huang Z, Mi L, et al. The potential role of inflammation reaction in COVID-19 related posttraumatic stress disorder. Asian J Psychiatr 2020;54:102405

270 Tremblay M-E, Madore C, Bordeleau M, et al. Neuropathobiology of COVID-19: the role for glia. Front Cell Neurosci 2020;14:592214.

271 Oliveira AC, Richards EM, Karas MM, et al. Would repurposing minocycline alleviate neurologic manifestations of COVID-19? Front Neurosci 2020;14:577780.

272 Solomon T. Neurological infection with SARS-CoV-2 - the story so far. Nat Rev Neurol 2021;17:65-6. 